\title{
MOLUCCAN CHRISTIANITY IN THE 19TH AND 20TH CENTURY BETWEEN AGAMA AMBON AND ISLAM
}

During the nineteenth and twentieth century the Moluccas were no longer the economically very attractive region of the two previous centuries. Java and Sumatra became the important regions. The period of very high prices for spices was over. The revolt of Pattimura on Saparua (1817) also made clear that the age of cruel measures and colonial oppression could not be continued. The close relation of various parts of the Moluccan islands with Dutch colonial authority became more and more expressed in a very strong involvement of the region, especially Christian Ambonese, in the colonial army. Because of the relatively high level of education in Ambon many Christian Moluccans went to others parts of the archipelago as teachers, police, or administrative officials. The city of Ambon, no longer a centre of the spice trade, became a major administrative centre for East Indonesia.

Between 1794 and 1815 there were no ordained Dutch Protestant ministers in the region, except for a few visitors, serving for one or two months only. As before, Christianity survived thanks to the local teachers who had also functioned as leaders of the congregations. They directed Sunday services with singing of Psalms, prayers and readings of sermons in the High Malay of the Leydecker translation of the Bible. Observers praised the congregation coming to the service for the neat, all-black clothing. Especially at the Lord's Supper those who were admitted were very earnest and serious. But this seriousness was also coloured with joy when the congregation did what they liked most: melodious singing, often in parts. Some local teachers preached by themselves during Sunday service but most of them read sermons written by Dutch ministers. In the course of the nineteenth century the former structure of the Christian church was restored again, with ordained Dutch ministers at the top of the hierarchy, and with better qualified Moluccan teachers at the local level. Notwithstanding the introduction of some elements of individualistic, pietistic spirituality, inspired by the missionaries of the NZG who served congregations until the 1850 s, the Christian minority (never more than $45 \%$ in the whole region) remained closely connected to the colonial administration. This government orientation had not only financial consequences, but also it fostered the specific Christian-Moluccan identity.

In this contribution we will first focus on the organisation of the Protestant Church, its personnel and the education of the faithful. History shows that 
these aspects received the highest priority in the process of consolidation and rehabilitation in the life of the church. The strategy of pioneering leaders like Joseph Kam in Ambon (1815-1833) and his colleagues was to seek a rehabilitation of the life of the church as a consequence of not only the financial but also the moral bankruptcy of the VOC. This was an effort that had to be continued until the twentieth century. In the second half of the twentieth century, besides discussing the three classical 'self-s' of self-propagating, self-financing, and self-governing, we will seek attention for the ecumenical relationships with other denominations, relations between church and state, with Islam and finally for the role of the Christian church in social-economic development.

During the last decades of the VOC the level of the church's service had declined drastically, most of all in its Dutch personnel. During the 1780 s there were still three ministers for the Ambon congregation, but between 1801 and 1815 no minister was serving the congregations in this region. The last minister had left Saparua in 1801. In Banda and Ternate the situation was similar. On the level of the villages the native leaders continued their duties. They had not received the full theological education of the Dutch ministers and they were not entitled to administer the sacraments, nor could they provide a full service to their congregations. But they sustained the local congregations and they prevented the return to tribal religion. Thanks to their commitment the Christian church survived, although instruction to the faithful was on a low level and there was no administration of sacraments.

In 1817 the Dutch returned after the British interregnum (1812-1816/7). This was the beginning of a new consciousness of the responsibility for the congregations that had been entrusted to them during the VOC centuries. Through several royal decrees the Protestantsche Kerk in Nederlandsch-Indië (commonly called Indische Kerk) was founded as a union of the various denominations that were present in the colony (Reformed, Lutheran, Baptist, Arminian and Mennonite). This was not only a sign of royal superiority over the Protestant Churches, it was also a proof of the king's firm wish to give intense and coordinated guidance to the local congregations that were often in decline. For the Protestants in the Dutch East Indies this policy meant that their church was under generous subsidy, but also under the bureaucratic and political supervision of the colonial administration. For much of the 19th and first half of the twentieth centuries there were not enough ordained and qualified ministers in the Moluccas. Therefore the government and the leadership of the Indische Kerk asked European missionaries who were sent by the missionary organisations to serve the Moluccan congregations. After Jabez Carey, Joseph Kam was the first to work under this constitution. Between 1819 and 1832 not less than 14 missionaries followed him to the Moluccas. Most of them, unfortunately, died soon or were not fit for this difficult work. 
After the death of Joseph Kam the role of the missionaries was brought more and more under the control of the ministers of the Indische Kerk. But the role of European missionaries, besides the ordained ministers of the Indische Kerk remained important, also after the formal breaking of the contract with the Dutch Missionary Society (NZG) in 1864, as we will see below.

The strong emotional ties of the Moluccan Christians to their religion became evident in the major uprising of this period, the Pattimura revolt of 1817. Thomas Matulesia, alias Pattimura, a Christian born about 1787, became a soldier in the British colonial army. In 1817 he did not accept the restoration of Dutch rule. Among the complaints of Pattimura was the fear that the payment of local Christian teachers by the central government would be discontinued again (as was already the case in 1810 when Daendels ordered the villages to collect money for the payment of teachers). This was seen by Pattimura as an effort of the Dutch to "dismiss the teachers and to destroy the Christian religion." He also complained about the new paper-money, replacing the old coins. The paper money could not be used for the alms-box in the churches, because tradition (adat) only validated gifts in coins. This could endanger the care for the poor. There were also rumours, that in this region of a mosaic of Christian and Muslim villages, the Muslims would be forced to embrace Christianity and that the liturgy would be changed. The Dutch were really surprised that religion was so prominent in the causes of the revolt. When the centre of the revolt was reconquered, the village of Saparua on the island of the same name, the Bible was found open on the pulpit of the church at psalm 17, "Hear, O Lord, my righteous plea." The head-teacher of Saparua, John Sahetappy, an orthodox Protestant, had defended the uprising. While Thomas Matulesia was executed, teacher Sahetappy was sent into exile to Java with many others, among them several teachers. In 1828 they were allowed to return and Joseph Kam wrote on that occasion, "our good Ambonese were released from exile and immediately after their arrival here presented themselves to me." The story of this revolt demonstrates the affection of the Moluccan Christians, living among Muslim villages, to their religion. It also shows the gap between the faith of the village communities and the official teaching of the ministers who were nominated by the central government. Much of the history of the nineteenth and twentieth centuries has to do with the tenacity of traditional Christianity (also labelled Agama Ambon) and the wish for purification and restoration, from the side of expatriate ministers and missionaries.

\footnotetext{
${ }^{1}$ Enklaar 1963:48-56.
} 
The dream of Joseph Kam (1815-1833):

a purified and committed Reformed Church

Because of the shortage of ordained ministers, the government had to ask help from the missionary organisations. For the Moluccas this was done with the nomination of Dutch missionary Joseph Kam (a member of the NZG) who had arrived in Indonesia thanks to the help of the London Missionary Society. Between 1815 and 1864 the NZG provided the most important support in personnel for Protestantism in the Moluccas. The first of them was Joseph Kam.

Joseph Kam, born in 1769 in the Netherlands in a Reformed milieu, studied for some time with the Moravian Brothers in Zeist, where he was deeply imbued with a pietist spirituality. As an adult he worked some twenty years in the leather trade. He married in 1804, but when his wife died in March 1806 , he decided to follow his vocation as a missionary. After being accepted by the Netherlands Missionary Society in 1808, he received some individual tutoring with learned and pious ministers. In 1812, still in the midst of the Napoleonic wars, he went to Britain for further missionary training, and to look for a way to enter mission territory. The London Missionary Society helped him to travel to Java in 1814, where the British government assigned him to work as a minister for the Moluccas, based in Ambon where he arrived on 3 March 1815. Kam was the first ordained Reformed minister in the whole of East Indonesia since 1801. He combined the ideas of pietism (organising revivals, prayer meetings and evangelism) with elements of the Reformed Church (the service of preaching and the sacraments, application of church discipline, and church organisation).

In Ambon, Joseph Kam was preceded by Jabez Carey, son of the famous Baptist missionary in India William Carey. Jabez Carey arrived in Ambon in 1814, at the request of the British Resident of Ambon, Byam Martin, but had to leave the country in 1818 because, after the end of the British rule in 1817, the Dutch government did not permit a British minister in the Outer Islands. Besides, as a Baptist missionary, Carey was not suitable for a blend of Christianity that connected ethnicity and religion as strong as the Ambonese did. Jabez Carey rejected the baptism of children, while Joseph Kam saw it as one of his first duties to baptise all those born in Christian families since the last minister had left the region in 1801 . Their number was so great that for many months Kam introduced a maximum of 120 children per Sunday. ${ }^{2}$

2 In 1815 Joseph Kam baptised 2919 in Ambon, 1290 in Haruku, 2538 in Saparua and 650 adults in Seram (Enklaar 1963:179). Carey worked later for a long time in North India. (Müller-Krüger 1968:134) In 1823 the Swiss J. Bär arrived. He was sent by the Dutch Missionary Council, NZG, and stayed in this region until his death in 1851. Like Joseph Kam he received a government salary. (De Jong \& Van Selm 1999:54). 
As the principal minister for the Moluccas, Kam made yearly extensive travels, partly in his self-built schooner. ${ }^{3}$ In 1821 there were, outside the town Ambon, schools and congregations in 28 villages on the island of Ambon; Haruku had 7 congregations, Saparua 13, Nusalaut 7, and Seram 13 and there were small congregations on Buru, Manipa and Boano. This was only the Central Moluccan region. During some of his trips Kam went as far as Ternate and the Minahasa in the north, or to Tanimbar and Aru in the south. ${ }^{4}$ The ceremony attached to such pastoral visits was already established during the past centuries, when most remote villages also were only visited by an ordained minister once a year at the most. After arrival at the coast the minister was greeted by the whole congregation, including the village head and his council. While singing psalms and hymns, the group went in procession to the village church, where a service was held as the beginning of a series of consultations, sermons and services that could take a few days. Local teachers were inspected and if not available they were sought from the capital.

Soon after his arrival in Ambon the 45 year old Joseph Kam remarried with a Eurasian lady Sara Maria Timmerman, the daughter of a rich Eurasian merchant of Ambon, at that time 18 years old. She had a good education and was of great help to her husband. ${ }^{5}$ Kam held no formal school, but he kept some 10-16 promising young men in his house, where they received, for several years, regular instruction from his wife and the Meester Besaar or head teacher of Ambon. The course was officially called "Institute for the Education of Qualified Assistants." ${ }^{\prime 6}$ One of the largest elementary schools of the residency (that counted about 77 schools) was established within the compound of Kam's house in Ambon and these candidates also did some work in this school. Besides, they had to work in Kam's printing press and on his schooner. After some five years of training they could be sent to one of the vacancies to become a teacher in the regency.

Kam was active in the propagation of Christian reading (bibles, psalm books, catechisms, collections of sermons for places where no ordained minister was settled) and he printed these in his own office or ordered them from outside. Occasionally Kam noticed that members of the congregation knew the hymns and psalms by heart and held the hymnbooks upside down! Instead of the very formal Reformed Christianity of the previous century, Joseph Kam introduced a warm and much more personal piety in the revival style of the Moravians. The main agents of this reform were the teachers who were educated by him

${ }^{3}$ His 1826 pastoral trip is described in De Jong \& Selm 1999.

${ }^{4}$ List of the travels in Enklaar 1963:72-74. List of the schools and congregations: ibid. 175-178.

${ }^{5}$ A sympathetic picture in Enklaar 1963:43-44.

${ }^{6}$ Instituut voor de Opleiding van Bekwame Medehelpers; Enklaar 1963:114. De Jong 2002: $79-80$. 
in person and sent out by the colonial government, with a salary and with the authority of the resident of Ambon. In his 1825 trip to the south-eastern islands of the Moluccas, Kam visited seven of them and the resident who had organised this trip where he was the main inspector, ordered eleven more to be stationed on various islands. ${ }^{7}$

After Francis Xavier and Justus Heurnius, Joseph Kam has been called "the third apostle of the Moluccas." ${ }^{\text {He }}$ was by far the most successful in his own lifetime. Like his predecessors he brought the European Christianity of his time. He was a severe fighter against idolatry and pagan remnants. In 1819 he launched in several places on Ambon a special action against statues, jars and sacred items related to the ancestor cult. Some of these objects were thrown in pieces in front of the population of villages or tied to heavy stones and cast in the sea. In the island of Seram, the tribal religion was even more evident. Only some coastal villages had accepted Christianity or Islam. The visiting minister Sytse Roorda van Eysinga saw in the early 1820s that schoolboys up to the age of 14 years took off their cloths when they came out of class and went naked in the Christian village of Kamarian. Therefore he considered the place not suited for a Dutch minister with his wife. This remained so for several decades: only in February 1858 missionary A. van Ekris settled in Kamarian. After some time his garden was destroyed, many things from his house stolen; people refused to sell food to him, and he was cheated in many ways. ${ }^{9}$ In another place on the south coast of Seram, Elpaputi, there were in 1818 still many skulls, a result of the still continuing head-hunting, placed in the baileo, the town hall. ${ }^{10}$ On the level of the central administration, it was resident and staff as well as the missionaries and ministers who promoted the sole and uncompromising adherence of orthodox Christianity. But on the local level the raja, the hereditary village chief, still fostered, besides formal confession of Christianity, many aspects of traditional Moluccan religion. The village teacher often had neither the authority nor the education to make drastic changes. In the villages the teacher (in most cases coming from another place) was not only recognised by the central administration, but was among the local elite, very often second only to the hereditary village chief or raja.

Joseph Kam was, above all, the reorganiser of congregations that were guided by teachers who gave instruction and said their prayers in traditional Malay. Some people gave him the nickname Tukang Sakramen or 'Sacramentalist' for his frequent and sometimes easy administration of sacraments, especially

\footnotetext{
${ }^{7}$ De Jong 1999.

${ }^{8}$ H.J. de Graaf 1977:208.

9 Coolsma 1901:693.

${ }^{10}$ For some examples see Enklaar 1963:79-80; there also 34-39 for various judgments about Moluccan Christianity in the early nineteenth century.
} 
in places he could visit no more frequently than once per year. In his period of duty 14 more missionaries arrived, but most of them died quickly or were unfit for the difficult task. The best were for some time instructed in Ambon by Kam himself and then sent to other places, like Reynt le Bruyn who, between 1819 and 1829, restructured the Protestant Church in Kupang, Timor, and the missionaries Johann Schwarz and Johann Riedel who, in 1831, began the very successful mission in Minahasa. In 1837 the Central Moluccan Christians totalled 35,877 baptised, not a dramatic increase on the 30,435 of the 1821 statistics. After the turbulent period of the collapse of the VOC and the English rule, they had found their place again in the state administration.

\section{Bernhard Roskott and the organisation of the teaching of the Ambonese Church (1835-1864)}

Bernard Roskott, was a qualified teacher, not a minister. He was in 1834 sent by the NZG to Ambon where he arrived in March 1835. He started a much better training for teachers, the Teachers' Training School of Batumerah, 30 minutes walk from the town of Ambon, where he was the principal until 1864. From 1843 he had P. Picauly as his major assistant. Together they ran, besides the teachers' training, also a primary school, where the older students could practice their skills. Roskott was a full-time teacher who maintained a severe daily schedule for his pupils. A school day started with prayers, fourpart singing and instrumental music (flutes and the small organ, played by Roskott himself). After formal prayers and singing, pupils of the first form were stimulated to write their own short compositions and to practice such new music using verses of the bible. Picauly then took the preliminary students to his classroom for the basic subjects that should be taught in the elementary schools: Malay language, handwriting, arithmetic, general and especially biblical history and geography, singing and flute-playing. Roskott took the older students himself. In the afternoon students had to work in the garden, because Roskott's estate looked like a small plantation, where the pupils could train in agricultural skills. The students practiced some carpentry, often worked in the printing shop, already set up by Joseph Kam, and were trained in housekeeping according to European tradition, in this respect supervised by Mrs. Roskott.

Bernhard Roskott gave much attention to the proper understanding of the classical Malay used in school and church. He wrote a Malay reader and a special book explaining the high-Malay words of the Leijdecker translation of the Bible. Visitors praised his school for its very disciplined and efficient teaching, but criticised the content. Biologist Dr. P. Bleeker was disappointed to see that only a little natural history was taught, although this could make 
the Moluccans "into industrial and more practical people." Roskott himself found it sufficient that he explained natural phenomena in a general way "to cure the children of the native population from superstition and popular fears and prejudices." ${ }^{11}$ Roskott's teachers' training school started with 12 students in 1835 , and counted 18 students in 1855 . At that time already 82 teachers were sent to various places in the region, most of them (61) in Ambon, but also three in Manado, ${ }^{12}$ one in Ternate and six in the Aru-archipelago. He was at that time more and more seen as a producer of the best native teachers one could find in the region, but he also realised that his institute was not keeping pace with the progress of the period. His students were not the best he could imagine. For some time he even thought of going to Java to start a much larger training institute under much better conditions.

Roskott was not a tireless and frequent traveller like Joseph Kam. Between 1836 and 1850 the villages outside Ambon town were only visited twice. In 1851 Roskott was formally nominated inspector of the government schools and this pushed him to make trips for inspection, but in fact he limited his travelling as much as possible. Already in the 1840s he realised that the graduates of his school needed continuing supervision. Roskott trained his students to become champions of orthodoxy. In their villages, however, they had to deal with the established traditions of the Agama Ambon and the village chiefs. Roskott proposed about 1840 that the civil administration should be withdrawn from the traditional rulers and put in the hands of the teachers. This would have involved some kind of Protestant theocracy for the Christian villages. In 1842 this proposal was not only rejected by the resident but at the same time it was decided that the NZG should gradually withdraw from the Moluccas. Missionaries should be accepted within the Indische Kerk, the Protestant Church of the Indies. In 1850 a formal decree was issued that missionaries should not interfere in the management of the schools, and in 1867 the last more or less independent missionaries who worked under formal authority of the NZG were accepted as Assistant Ministers (hulppredikers) in the Indische Kerk in the Moluccas. Besides the fully ordained ministers, the European missionaries would continue to play a role in the Moluccan Protestant Church. Their number also would remain small and never exceeded the total of 13 for the whole of the Moluccas. Due to the lack of ordained ministers (who had to be trained at Dutch universities) the Indische Kerk had to rely in this way on the personnel of the missionary societies, but the situation caused more

\footnotetext{
${ }^{11}$ For detailed descriptions of Roskott's boarding school: Kroeskamp 1974:65-85 and Chr. G.F. de Jong 2006, I. For the visit by Bleeker, see p. 72 .

12 One of these was W. Hehanusa (1799-1887) who later became one of the first ordained Indonesian ministers, Van den End 1980-I:165.
} 
and more tensions. ${ }^{13}$ Roskott with his institute remained the backbone for the training of native teacher-preachers, but because of the many conflicts among the missionaries he could not give the same level of inspiration as Joseph Kam. After his wife had died he married a young woman with whom he already had a child and for this reason (besides growing criticism on his style of education) he was dismissed by the NZG, in 1864. He stayed on in Ambon until his death in 1873.

The Moluccan Christians were proud, convinced, but certainly not specifically missionary Christians. We have already seen above the case of the Pattimura revolt in 1817, where one of the objections against the return of Dutch rule was the fear that they would try to convert the Moluccan Muslims. Another case occurred in the 1840s in the island of Buru. The government official, the posthouder, a native Ambonese, wrote in 1846 to the governor of the Moluccas in Ambon, J.B. Cleerens (1846-1850), that he had made propaganda among the population and had found a number of people who were willing to embrace Christianity. In Ambon, however, minister A. van Davelaar and Bernhard Roskott were not so enthusiastic. They were not yet sure about the level of education of the candidates for baptism and also suggested that possibly these people had tried to escape obedience to their Muslim chiefs by becoming Christian. The governor even sent the zealous posthouder a reproach "because he had lost sight that conversion is an ecclesiastical affair and his views did not go along with the rulings of the institution." Only some decades later did both church and state became more active in sending Christian teachers to regions where the race between Islam and Christianity was still undecided. ${ }^{14}$

\section{The pastoral and missionary strategies of the Indische Kerk, 1864-1935}

For the period after 1864 we see two conflicting tendencies among the Moluccan Christianity. With the return of the full authority of the Indische Kerk the Christian community and its leadership was again brought under the supervision of the civil administration. Against this policy was the movement towards separation of state and church that resulted in the establishment of an autonomous Protestant Church in the Moluccas (Gereja Protestan Maluku, GPM) in 1935. The first realm where this separation was attempted (but never fully accomplished) was education.

\footnotetext{
${ }^{13}$ In 1854 the number of ordained ministers for the 'resort Ambon' was reduced from four to two; besides there was a minister for Ternate and one for Banda. Quite often, however, even these four positions were not occupied. Van den End 1989-II:59.

${ }^{14}$ Enklaar 1947:64-66.
} 
The newly appointed first national inspector for native education, J.A. van der Chijs, made in 1867 a tour of inspection to the Moluccas. His conclusion was that the Muslim schools concentrated on the study of Arabic and the Qur'an (reading first, understanding came much later or never). In the Christian schools he saw the same pattern. Another more or less foreign language was the subject of education: the classical high-Malay of the bible, the biblical stories and the prayers and sermons for church use. Geography lessons were restricted to the map of Palestine and the travels of Paul (if schools had a map at all) and history was identical with biblical history. Van der Chijs concluded, "The social position of these teachers is until this day so ambiguous that it is impossible to discern whether they are schoolmasters or teachers of religion. Their common name is, indeed, schoolmaster, but we could also call them catechist or comforter for the sick." ${ }^{15}$ This inspection by Van der Chijs was the beginning of a great reorganisation of education in the Dutch East Indies. It was the start of a continuing cleavage between Islamic and Christian education. Islamic education stayed outside government influence and support, while Christian education became the starting point for a development towards a broader national system of education. However, this development also involved the strategy that a school-teacher could no longer automatically be the preacher for the local congregation.

The number of ordained ministers and their location (two in Ambon, one respectively in Ternate and Banda) was more related to their pastoral service for Europeans than for native Indonesian Christians. In fact, since the arrival of the VOC, it was the local teachers who had given guidance and leadership to the native congregations. After the separation of school and church, that started in the 1860s, besides the guru midras, the school teacher, the guru jemaat, the teacher of the congregation was assigned the task of preaching and leading the service on Sundays and several occasions during the week, catechesis, pastoral visits to the sick, burials and further pastoral tasks. The same government decree of 1867 that formulated the position of expatriate missionaries as 'assistant ministers' also stipulated that one of their duties was to give personal tutoring to the guru jemaat, who could become an inlandsch leeraar, literally a 'native teacher' but in fact to be understood as a native minister. They would have the right to administer the sacraments of Baptism and the Lord's Supper. In 1880 the first of these native ministers passed his examination and he was ordained in 1881. In 1885 special theological schools were founded for native ministers, STOVIL (School tot Opleiding van Inlandsche Leeraren), the first two in Ambon and Tomohon. In 1935 nearly all 347 native

${ }^{15}$ Steenbrink 1974:3-4. 
ministers within the Indische Kerk served congregations in the Moluccas, who were assisted and controlled by their own church councils.

The development towards a fully recognised native minister did not run as smoothly as suggested above. During the first decades after the 1880 s the native ministers could exercise their duties only under strict supervision of the few expatriate full ministers of the Protestant Church in Ambon, Ternate and Banda. The hierarchical system still survived, for rather a long time, with the consequence that administration of the Lord's Supper was separated from the administration of baptism. As we will see below, for strategic reasons, in quite a few cases baptism was administered quickly also to people with very little knowledge of the Christian faith. But in the matter of church discipline and admittance to the Lord's Supper the Moluccan church kept to very strict rules both for the receivers and the administrators. From the ordination of the first native minister onwards there were limitations to their jurisdiction. Only in 1916 was it decided that native ministers after 10 years of service would have the power to administer both sacraments, and even the implementation of this rule was delayed for a few years. This regulation applied in the regions of East Indonesia where the Indische Kerk had many native members, in the Moluccas, Papua, Timor, and the Minahasa.

On 29 January 1821 Joseph Kam had founded an Auxiliary Missionary Society in Ambon, the Hulp-Zendelinggenootschap. Its purpose was to give support in the Moluccas to incoming missionaries from Europe but it should also prepare native Moluccan workers for missionary activities among pagans and slaves. For these purposes Joseph Kam also organised weekly prayer meetings. ${ }^{16}$ These missionary activities were not directed to Ambonese Muslims. As we have seen above in the discussion of the Pattimura revolt, there was a strong feeling among Ambonese that the division of society among Christians and Muslims had become part of the Moluccan identity. In 1926 Hendrik Kraemer noted that several ministers and evangelists said with pride, "Relations between the two groups [Christians and Muslims] are excellent. They leave each other completely alone." ${ }^{17}$ This static situation of living side by side, according to Kraemer, was some kind of apartheid, where the Christians felt their situation as a privileged and higher status (pangkat) compared to that of Muslims or pagans. They used also the expression pangkat serani or 'Christian status' to indicate their special position. Efforts to bring Muslims to this status and to convert them to Christianity would disturb the social balance. ${ }^{18}$ It was a quite usual practice that Christians would receive a child of a Muslim branch of the same clan into their house for school education, because Christian villages had

16 Enklaar 1963:125.

17 Kraemer 1958:22.

18 Kraemer 1958:14. 
much better schools than the Muslims. These children were called anak piara, foster child. In this case they would take care that these Muslim children would never eat pork. Christian sections of a mixed clan helped the Muslims of the clan at the restoration of a mosque and vice-versa and there are examples of ritual utensils, like an offertory-box in a church, that were donated by Muslims. Christians and Muslims descending from one ancestor were bound together in the pela-relations. They were obliged to give mutual assistance also in religious matters, to socialise at Christmas or the end of Ramadan, and to defend each other. Every few years big celebrations were held to intensify the pela-relations with ceremonies, often still resembling pagan rituals and therefore criticised by orthodox Muslim and Christian preachers alike.

Around 1900 several missionary organisations were founded in the Central Moluccas, like the Fonds Indjil (Gospel Fund, Ambon, 1880s), Eltheto [Come!], Biji Sesawi [Mustard Grain], and Ora et Labora [Pray and Work]. These organisations show the role of the better-educated ministers and their flock, because of the use of Greek and Latin terminology. The Central Moluccan Christians, while reluctant to preach to Muslims, were still quite supportive of missionary work among pagans in remote areas, as we will see from several examples below. These were not only activities by professional missionaries. Many initiatives were taken by Ambonese who worked in the civil administration as teachers or as policemen. Wherever they lived they often tried to establish a small community interested in Christianity and to find support for these people from the Central Moluccan churches.

Their long relationship with Dutch colonialism, and some kind of pride for their affinity to the ruling class, did not prevent the rise of nationalism among the Central Moluccans. The Sarekat Ambon or Ambonese Union was the first outspoken nationalist organisation outside Java. It was started by the journalist A.J. Patty who became suspected of communism, like many of his colleagues at the time. In that same period some efforts were made to give the Moluccan Christians an organisation independent from the Indische Kerk. It was the Rev. T.J. van Oostrom Soede, minister in Ambon between 1926 and 1932, who initiated this way to a more outspoken Moluccan Christian identity that led to the erection of a distinct Moluccan Protestant Church (GPM) in 1935. He nominated the first Moluccan, the Rev. J. Loppies, to become director of the school for the training of evangelists (guru jemaat) and another, the Rev. W. Tutuarima to become director of the STOVIL, the College for Native Ministers. In 1928 a drastic revision was made in the institution of the local church councils. Until that year their members were nominated by the ministers, as most things were done from the top down in the Indische Kerk. Since 1928 larger and better developed local congregations could already elect their church councils and many more would follow later. In 1932 the Rev. H.H. van Herwerden made the draft for the constitution of the future 
GPM in a Presbyterian style giving preference to the autonomy of the local congregations, governed by ministers, elders and deacons. Still, in its constitution some link with the national Reformed Indische Kerk remained intact. In 1933 a proto-synod was held and on 6 September 1935 the new GPM held its first constitutive synod. For the financing of the Church this new constitution had no direct consequences. This was for a larger part still the responsibility of the colonial government.

\section{The independent Protestant Moluccan Church in a new society, 1935-2000}

Between 1950 and 1965 the Moluccan Protestants had to find their position in the new social-political situation. Dutch colonialism was abolished, and this meant that the privileged position of the Protestant church, already diminished since 1935, came to an abrupt end. Instead of being close to a national government the GPM had to find its own way. In some way the colonial identification between Protestantism and government was continued by the dominant position of Protestants in the administration of the province of the Moluccas, but on the national level (that also influenced the provincial situation) GPM started to develop the more prophetic style of a major social organisation outside and sometimes also opposite the government. Church leadership hesitated between the two extremes and we will see more examples of this in this section.

The general principle of the GPM became the separation of church and state with recognition of the autonomy of both institutions. In this structure the church has its own obedience to the word of God and in various situations the church may have the duty to witness to God's Word to society and the state. But the church, living within society, cannot take a position far away from the government and should try not to enter into strenuous relations with the government.

This had already become clear during the Japanese occupation of the Moluccas, 1942-1945. In the Reformed tradition churches obeyed the biblical principle of Rom. 13:1, "Everyone must submit himself to the governing authorities, for there is no authority except that which God has established. The authorities that exist have been established by God." Therefore the GPM felt obliged to acknowledge and to honour the authority and power of Japanese rule. But on the other side the church was conscious of its prophetic role, like to prophets of the Old Testament. This became clear in the protests against the Japanese elements that were introduced in society and church, such as the ritual honour to be given to the Japanese flag before the beginning of Sunday services in the churches. The GPM also protested against censorship of the sermons that were to be delivered at Sunday services. This position was not 
accepted easily by the Japanese authority. Among the members of the GPM 32 ministers (among them 4 Dutch citizens) and 47 guru jemaat were killed. Several of them were beheaded by the Kempetai, the Japanese secret police. This was a much higher number than in comparable regions, like Minahasa. It may have been related to the forthright attitude of the Moluccans, different from the more quiet Minahasans. ${ }^{19}$

A similar conflict, although on smaller scale, occurred in 1957, when the GPM made an official statement against several members of the military authority who urged members of the GPM to work for them on Sunday, at the very hour of the church service. This measure was considered to be against the fixed tradition of the GPM to hold service at that particular time. This tension between the GPM and the local government, controlled by the military, increased when the printed statement of the church was confiscated by the police at various places (among these on Saparua). Finally, this matter could be settled only after negotiations between the military and representatives of the Protestant Church.

During the Japanese period the most important leader of GPM was Rev. Simon Marantika, born in 1909 and a graduate of the police academy (1934) and the theological school of Jakarta (1940). In 1942 he became chairman of the GPM Synod, a function he occupied most of the time until 1967 when his activities moved to ecumenical positions in the National Council of churches of Indonesia and within the CCA, Christian Council of Asia. Even more prominent in the early decades of GPM was Rev. Thomas Pattiasina (1916-1980), born in Saparua and after his education in Jakarta minister in the GPM, since 1946. He was an outspoken nationalist and therefore in 1948 dismissed from his position in the church until his rehabilitation in 1954. As chair of the GPM Synod between 1961 and 1976 he was most important in the process of leading the young independent church to maturity. His role for GPM is compared to that of contemporary Protestant leaders like Sihombing in the Batak Church HKBP, Wenas in Minahasa, Rumainum in Papua and Aniroen in West Java.

In the period 1960-1990 there were not many problems between the church and the local authorities. During this period the church received many subsidies for its schools, from elementary schools to secondary schools and colleges. Even the theological faculty received government subsidies. From its side the church also gave public support to many government programmes in the field of development like programmes for Planned parenthood, birth control. In its Synod of 1976 the GPM stated, "The presence of the Church through its mission to this world cannot be separated from the discussion of the many

19 Marantika, 1989:30-32; De Protestantsche Kerk 1946:8. 
problems in people and society because the Church has been sent for the benefit of this world and in the midst of the problems of this world."20

At the dissolution of the Royal Dutch Indies Colonial Army in early 1950 some 4,000 Ambonese soldiers rejected the choice between inclusion in the new Indonesian army or dismissal. The majority were Protestants but among them there were also some 300 Catholics and 150 Muslims. In the Moluccas at that time local Christian separatists rejected the formation of the unified Indonesian Republic in April 1950 and pleaded for the formation of an independent Moluccan state, Republik Maluku Selatan (RMS). Because of the political unrest in their homeland the Moluccan ex-soldiers of the colonial army were for some time registered as soldiers of the regular Dutch army. In this situation they were brought to the Netherlands, together with their families, in total some 12,500 people. Initially it was thought that this was a temporary measure, but this Moluccan group has since then remained in the Netherlands. Especially the Protestants among them fostered a 'theology of exile, dreaming of a return to Indonesia in order to live in an independent Ambonese state. In the Netherlands the tradition of the piring natzar was stimulated from the 1990s on by young Moluccan ministers who tried to eliminate the 'exile theology' and the outspoken nationalism of their Christian compatriots. The piring natzar is a 'plate of vows', put on a table together with the hymn book and the bible. This sacred place was traditionally for offerings in memory of the ancestors. But now most often food and money, is put on the plate and after the intention of the prayers has been realised, the gifts are put in the hands of the ministers. The continuation of the separatist RMS ideology by a number Moluccan Christians, both in Indonesia and the Netherlands, has caused much trouble in Indonesia and we will see below how the subject became an important issue during the inter-religious fighting of the period 1998-2003. The introduction or rather the official promotion of the piring natzar by a group of young Moluccan ministers in the Netherlands has also caused a conflict between church leadership in the Moluccas and the Moluccan Protestants in the Netherlands. In the Moluccas the practice of piring natzar has long been considered one of the remnants of the ancestor cult of the agama Ambon, and since the nineteenth century orthodox ministers had tried to eliminate this pagan practice that now became stimulated and propagated as acculturated Protestantism by some young ministers abroad. Because the Moluccan community in the Netherlands continued the dream of this independent Ambonese Christian nation they rejected the idea that they would become part of the Reformed Church in the Netherlands, but they

20 "Kehadiran Gereja dalam tugas pengutusannya ke dalam dunia, tidak dapat melepaskan diri dari setiap permasalahan yang menyangkut seluruh aspek kehidupan bangsa dan negara, karena gereja diutus untuk dan di dalam kesulitan dunia." 
founded a Provisional Moluccan Church in the Netherlands. Due to several conflicts and schisms, there were about six Moluccan Protestant Churches in the Netherlands in 2000 with some 50,000 members. They were present at the meetings of the synod of the GPM and had also the status of observers at the assemblies of the Indonesian Council of Churches (PGI). ${ }^{21}$

Before Independence, GPM was organised in a very centralistic way. All rulings were established in a top-down structure. In order to counteract this undemocratic system by a more egalitarian approach, it was decided at the 1978 synod that three church centres were to be opened, besides the central office of the church in the town of Ambon: Ternate for the Northern Moluccas, Masohi for the Central Moluccas and Tual for the Southeast Moluccas. In the daily management of the synod also three visitors for the three regions were nominated. Their function was to communicate between the central office and the klassis (the ecclesiastical district, presbytery). The Catholic Church had the seat of its diocese in Ambon, but erected also regional centres in Ternate, Langgur (close to Tual) for the Kai islands, and Saumlaki for the Tanimbar islands.

Until Independence, education was the basic social activity of the Christian churches. The fast growth of the population and the need for more graduates from secondary schools and specialised universities put a great challenge to the educational institutions of the churches. In the 1950s many schools were taken over and numerous new ones founded by the Indonesian government, but still many schools continued under the responsibility of the churches as private schools, most often with partial subsidy from the Indonesian government.

During the colonial period the education provided by the church was mostly at primary or secondary level (besides the theological education at STOVIL), but after the 1950s vocational schools, a large variety of colleges for nurses, teachers' education and a fully equipped university, UKIM, Universitas Kristen Maluku, were opened. In the early 1970s GPM had the responsibility for 330 elementary schools in the Moluccas. Only in a few other regions had Protestant churches erected more schools (in the Minahasa 367, in Papua under GPM responsibility 551 and Timor 452, but all the other Protestant churches had considerably fewer schools). There were 18 secondary schools and three vocational schools under the supervision of this church. At that time the GPM had 607 local congregations, served by 364 ministers, 95 evangelists ( $g u r u$ injil) and 26 assistant teachers for the congregation (guru jemaat). ${ }^{22}$

${ }^{21}$ Antje van der Hoek 1994. Piring Natzar 1995.

${ }^{22}$ Ukur \& Cooley 1979:135 and 228. 
During the period of Japanese occupation, 1942-1945, the new colonising rule had instituted an enforced unification of the Christian churches in this region. The Ambon-Syu Kiristokyo Rengokai (AKR, the Ambonese Union of Christian Churches). After the surrender of the Japanese army this body was terminated, but it was not the absolute end for cooperation between churches. With the increase of churches who played a role in many regions in the Moluccas, some types of ecumenical cooperation continued or were initiated. Especially the common celebration of Christmas became very popular, and in general common celebrations were the most successful expression of ecumenical activities. On the official level, there remained strained relations between the established churches like the GPM and the GMIH (for this Halmahera church see below) with churches that were considered as intruders or new-comers like the Salvation Army, Seventh Day Adventists, Pentecostals and the Roman Catholics. GPM and GMIH were born in a tradition where each was the sole acknowledged Christian religious body in a specific region. They had grown in the tradition of the prevention of 'double mission' and considered other denominations as intruders in 'their territory.' As a state-funded church, GPM also had a strong idea of being the more or less official public religion, at least until the end of the colonial period. It took some time before these churches were willing to accept other churches as their equals in this region. Especially the cooperation within the Indonesian Council of Churches (DGI, later PGI) was very helpful for a better ecumenical mentality. The Full Gospel Church (Gereja Bethel Injil Sepenuh, GBIS) in Halmahera finally won much respect in the Northern Moluccas. These two churches, GMIH and GBIS, organised common bible studies and lectures that were frequently attended by women from these churches. On 25 May, the anniversary of the foundation of the Indonesian Council of Churches it has become common practice that GMIH ministers deliver sermons in the GBIS churches and the other way round. Also at celebrations of mixed marriage the cooperation of ministers from both sides has become a quite usual practice, even with the Roman Catholics. This has been a good means to reduce tensions that often occur between Christians of various denominations especially in many remote regions of the Moluccas.

Notwithstanding various improvements of the ecumenical climate, still many aspects of the former rivalry between the Christian denominations can be observed. In the atmosphere of the increased religious enthusiasm during the New Order regime of General Soeharto (1966-1998) there was much resentment related to the physical appearance of church buildings, schools and offices. All churches wanted to show their strength and growth through prestigious buildings. On the national level the Indonesian Council of Churches (PGI) is uniting the mainstream or classical Protestant Churches, but in the Moluccas there are also some more Evangelical-Pentecostal churches united in the provincial branch of the PGI. This Persekutuan Gereja-gereja Wilayah 
Maluku united not only the GPM and GMIH but also the more EvangelicalPentecostal Full Gospel Church (GBIS, already mentioned above), besides the Indonesian Bethel Church, the Gereja Tuhan di Indonesia (Church of the Lord in Indonesia), the Central Surabaya Pentecostal Church, the Salvation Army, the Gereja Kalam Kudus (Sacred Word Church) and the Gereja Perjanjian Baru (the Church of the New Testament).

\section{The Northern Moluccas: Halmahera, Sula and some other regions}

The largest island of the Moluccas, the mountainous and not easily accessible Halmahera, and the remote Sangir and Talaud islands had in the nineteenth century no longer any remnants of the period of early Portuguese missions. Especially the coast of Northeast Halmahera had come more and more under Islamic influence. However, from 1866 there was the beginning of the mission of the Utrechtsche Zendingsvereeniging in Halmahera. The most prominent missionary during the first decades was Hendrik van Dijken, who had arrived in the Indies as a Gossner missionary: a farmer without much formal education but with a strong body and a keen interest in many things, who came to the Indies to do missionary work besides his major job of manual work and earning his own income. He arrived in July 1866 in Galela. Initially Van Dijken and two missionaries of the UZV did not receive a permit from the Sultan of Ternate to settle among the inland people on the borders of Lake Galela, but in 1867 he founded a new village, called Duma after Isaias 21:11 where an oracle against Dumah (lit. 'silence') is pronounced ending in, "Morning is coming." A flood that occurred a few months after Van Dijken settled in this region, was seen by him as a divine punishment for the stubborn people who refused to accept his message. This interpretation brought the first seventy converts for Van Dijken. They moved to the Christian village of Duma where they received a thorough introduction to Reformed Christianity. Before moving they had to promise to renounce pagan practices, not to work on Sunday and to attend catechism and church services. To their great surprise they were not obliged to cut their long hair (as in the case of conversion to Islam).

Van Dijken was a clever and industrious man who did much reading and in 1873 he was ordained to become a full minister of the Reformed Church. His work proceeded very slowly, not in the last place because of the strict conditions he set for conversion: a thorough knowledge of Christian doctrine and faultless lifestyle. Only in July 1874 were the first five men and two women baptised and also immediately admitted to Holy Communion. In 1879 the first two elders for the church council were nominated as well as a Christian head of the village of Duma. After this, the raise of baptisms grew more quickly, but there were still cases where people had to follow 12 years of catechism classes before they were allowed to receive baptism. In 1895, after thirty years 
of work, Van Dijken had baptised 62 adults and 138 children. His flock in Duma was then about 150 people. Van Dijken died in June $1900{ }^{23}$

Van Dijken wanted to establish a small but pure and committed Christian village that lived quite isolated from the surrounding world. People who entered his village after firm promise to keep to the Christian law were prevented from continuing to have contacts with their former villages. In cases of marriage and burial Van Dijken was prepared to pay the fines for people who refused to fulfil the obligations to their relatives. Also for girls who could have produced a bride price for their families compensation was paid by the missionary village. Van Dijken tried some new food and cash crops for Duma in order to enhance its independence. But he proved to be a better missionary than a farmer. The chocolate plantation that he started was no great success.

In 1896 another missionary arrived, who would be the leader of the small but steadily growing Christian community for a decisive period of its existence. A. Hueting worked until 1915 in Northeast Halmahera and later continued his work in Buru. He settled at Gamsungi, somewhat to the south of Duma and Galela, in the region of the Tobelo tribe. Within one year of his arrival Hueting experienced a great opportunity for mission work. The chief of the Tobelo-the only tribe of Halmahera that was still in majority pagan-had come into conflict with the Sultan of Ternate, and was sent into exile. Thereupon the tribe revolted against the sultan, the nominal head of all the natives of Halmahera. In protest against the measures of the sultan there was a strong movement in favour of conversion to Christianity that resulted in about 3,000 baptisms between 1898 and 1900. Hueting had a quite different approach compared to Van Dijken. He divided the process of becoming a true Christian into three stages. People who applied for catechism lessons and expressed their wish for membership in the Christian congregation received immediately a surat murid, a written proof that they were trainees. After they had followed the catechism classes in a disciplined way for several months, they were baptised. Only after a longer period of catechism lessons and disciplined life as a Christian they were admitted to the Holy Communion as the final stage of initiation to Christianity.

At baptism the converts had to bring the material remnants of their pagan religion, like amulets and ritual objects, and these were burnt on a special place that was already destined to become the place for the church of this new congregation. In this way it was already, before the building of the church, a sacred place (keramat). The Tobelo Christians were not gathered in one village, but continued to live among their relatives, their own tribe and even among some Muslim families. Hueting also did not foster a drastic

${ }^{23}$ Van den End 1989:127; on Van Dijken: H. Reenders 1991:336-339. 
break with traditional customs. Traditional marriage was considered valid for Christians as well. No new Christian names were suggested at baptism. In this case the converts were sometimes more radical than the missionary. Quite a few converts of the Tobelo tribe wanted to have a biblical or more specifically Christian name. They also started to cut their hair, and short hair became the outer sign of being a Christian. The bride price was not abolished but the amount was severely reduced. In 1901, 1903 and 1905 the missionaries stimulated great meetings of all tribal people of Halmahera (both pagans and Christians) and many aspects of Halmaheran traditional law and practice were debated during these meetings.

After Van Dijken's death in 1900 the village of Duma became more open. It remained the centre of the Halmahera mission by virtue of its teacher's training school. Teachers who were trained in Duma were at the origin of many schools in Northern Halmahera and they also started new congregations. In the other centre of the mission, Gamsungi, a small hospital was erected. Until the Japanese occupation of 1942 the mission saw a steady growth but no spectacular results. There were not yet ordained ministers of Halmahera origin when the Dutch missionaries were confined in the Japanese concentrations camps in 1942. Out of the five ministers who were ordained in 1946 only one was a Halmaheran, three originated from Ambon and one from Sangir. In 1949 the Christian community that was born from the missionary initiative was formally transformed into the GMIH, Gereja Masehi Injili Halmahera (Evangelical Christian Church of Halmahera). This was just in time, because the foreign missionaries had to leave Halmahera in 1952 due to conflicts between the young Indonesian Republic and its former coloniser The Netherlands about the status of nearby West Papua. In 1980 about 105,000 or $45 \%$ of the population of Halmahera was Christian, the majority living in the most densely populated north-eastern region of Halmahera. ${ }^{24}$

As in other regions of Indonesia, also in Halmahera, it became obligatory to adhere formally to one of the five major religions in the wake of the anticommunist coup of General Soeharto in 1965. For Halmahera there is a quite curious report from the late 1960s which indicated that it was government officials or political parties who finally urged the last group of adherents of tribal religions to choose a religion, in fact to choose between Protestantism and Islam,

In Jailolo, the head of the Religious Administration, Christian [= Protestant] Sector, J. Manipa, asked the village chiefs, district heads and other officials to bring together all people who were known as adherents of tribal religions in that region. They were summoned to his office and were asked which religion they

${ }^{24}$ Besides the work by Van den End and Reenders, see James Haire 1981. 
would like to choose. If someone opted for Christianity, then he or she would be handed over to the evangelist (guru jemaat) of the Protestant congregation, because there were no Catholics here. If someone opted for Islam, he or she would be given to the Imam. In this way there were formally no longer adherents of a tribal religion in Jailolo. ${ }^{25}$

In a similar way also in the districts of Buli and Kau action was taken to register the last adherents of tribal religions to one of the five major religions of Indonesia. In Kau there were some problems, because older people objected to Islam as well as to Christianity. They finally were registered as Christians "because their children were already Christian."

A quite spectacular movement towards Christianity took place in the Sula archipelago, west of Ternate, in the 1910s. As we have seen above, until the beginning of the twentieth century the authority of the sultan of Ternate was recognised for native affairs within the framework of the colonial rule. Especially in religious matters he sometimes wanted to show his authority, but he had also traditional rights in taxes and income from forest. In 1910 the colonial government introduced a poll tax for the population of the Sula islands. The coastal population were the first to obey this new tax. In fact they were quite willing to accept the new rule, because they considered this as a recognition of their status as citizens of the colonial state and at the same time saw themselves no longer as citizens subjected to the Ternate administration and taxes. The Ambonese posthouder of Sula thereupon suggested that they should reorganise their society by living together in villages along the coast (which would facilitate the collection of taxes) and that they should become Christians. This suggestion was taken as a perintah halus, a gentle but clear command. In 1912 the posthouder notified the resident of Ternate about the 'wish' of the population to become Christian. The resident had already seen that some people of Sula had embraced Islam and he was happy with the strategy of the Ambonese posthouder. But the resident had to remain neutral in religious affairs and even the assistant minister M. Birkhoff, who served the congregation of the Indische Kerk in Ternate, was only allowed to visit existing Christian congregations. He could not preach and administer baptism to pagans. The resident of Ternate therefore made a trip to Sula together with assistant minister Birkhoff. During a short stop in Taliabu 185 people were baptised. This was enough to add five 'well-establish congregations' to the statistics and to allow the Moluccan Church to send teachers to these places who would be paid by the government. ${ }^{26}$

In September 1914 a small revolt started in Jailolo against the tax collectors of the sultan of Ternate who asked from Muslims and non-Muslims the

${ }^{25}$ A.L. Fransz (ed.) 1976:79.

${ }^{26}$ Enklaar 1947:68-71. 
same amount of money. The revolt was quickly crushed, but it provided an opportunity to arrest Sultan Usman for lack of cooperation with the colonial government. An additional argument against his rule was that he opposed the introduction of compulsory basic education. Sultan Usman was sent into exile to Java and in fact the sultanate was abolished. ${ }^{27}$ This political move reinforced the position of Christians in the region. There was no triumphant comment, as if the siege over the Muslim sultanates was complete, some four centuries after the arrival of the first Iberian vessels. During the period 1945-50 and more powerfully even during the difficult period of 1998-2002 the sultanate of Ternate attempted a revival, but until now without clear success.

\begin{tabular}{|c|c|c|c|c|c|c|}
\hline $\begin{array}{l}\text { Moluccan Christians } \\
\text { (mostly Protestants) }^{28}\end{array}$ & Ca. 1720 & Ca. 1823 & \multicolumn{2}{|c|}{ Ca. 1897} & \multicolumn{2}{|c|}{1937} \\
\hline Ambon + Lease & 24,216 & 25,556 & \multicolumn{2}{|c|}{50,083} & \multicolumn{2}{|c|}{72,000} \\
\hline Banda & 2,000 & 1,289 & \multicolumn{2}{|c|}{1,355} & \multicolumn{2}{|c|}{4,537} \\
\hline Ternate & 1,500 & 700 & \multicolumn{2}{|c|}{1,141} & \multicolumn{2}{|c|}{1,912} \\
\hline Seram & & & \multicolumn{2}{|c|}{4,869} & \multicolumn{2}{|c|}{27,915} \\
\hline Buru & 151 & 171 & & & \multicolumn{2}{|c|}{823} \\
\hline Wetar & 121 & & \multicolumn{2}{|c|}{325} & \multicolumn{2}{|c|}{1,475} \\
\hline Kisar & 409 & 200 & \multicolumn{2}{|c|}{2,537} & \multirow{2}{*}{\multicolumn{2}{|c|}{$\begin{array}{r}3,533 \\
228\end{array}$}} \\
\hline Roma & & 9 & \multicolumn{2}{|c|}{200} & & \\
\hline Damar & 378 & 200 & \multicolumn{2}{|c|}{1,605} & \multicolumn{2}{|c|}{1,862} \\
\hline Leti & 233 & 150 & \multicolumn{2}{|c|}{975} & \multicolumn{2}{|c|}{3,615} \\
\hline Moa & 112 & & \multicolumn{2}{|c|}{740} & \multicolumn{2}{|c|}{2,548} \\
\hline Lakor & $?$ & & & & \multicolumn{2}{|c|}{273} \\
\hline Luang & $?$ & 200 & \multicolumn{2}{|c|}{396} & \multicolumn{2}{|c|}{946} \\
\hline Sermata & $?$ & & & & \multicolumn{2}{|c|}{2,468} \\
\hline \multirow[t]{2}{*}{ Babar } & 80 & & & & \multicolumn{2}{|c|}{1,132} \\
\hline & & & Prot. & $\mathrm{RC}$ & Prot. & $\mathrm{RC}$ \\
\hline Tanimbar & $?$ & $?$ & 65 & - & 22,014 & 11,637 \\
\hline $\mathrm{Kai}$ & $?$ & $?$ & - & 743 & 12,163 & 17,579 \\
\hline Aru & 274 & 400 & 2,062 & - & 6,505 & - \\
\hline
\end{tabular}

Protestants and Catholics in the Southeast Moluccas: Aru, Kai and Tanimbar

Since the 1880s the arrival of steamships resulted in a more intense trade and travelling in many of the outer islands, including the various quite extended archipelagos of the Southeast Moluccas. In the wake of more intense trade, the colonial administration followed with permanent posts, and in this same

\footnotetext{
27 Van Fraassen 1987-I:60.

28 Adapted after Van den End 1989:65.
} 
stream of intensifying contacts there was the spread of the major religions of Islam and Christianity. Islam and Protestantism, both already active in the region during the preceding centuries, did not develop outspoken and planned missionary activities that caused the spread of their religion, but the growth of Christianity first of all should be seen as a consequence of more intense contacts of trade and administration. As to the Catholics, because of their absence in this region, it was a clearly planned action that caused the expansion of their religion. This started in 1886 with a request by a German Lutheran businessman in Tual, the major harbour for the Kai islands, Adolf Langen, to Bishop Adamus Claessens of Batavia that missionaries should be sent to convert the population of the Kai islands who in majority would be willing to accept Christianity. In a letter of October 1887 Langen mentioned that already four Protestant teachers from Ambon had tried to open schools, but had failed and two had left already. He thought that a solid Catholic action could be more successful.

The first Jesuit missionaries arrived in Tual on 1 July 1888 and discovered that this major harbour of the islands was in majority Muslim. Neighbouring Langgur, however, was still pagan and in 1889 the first baptisms took place after missionary Jan Kusters had stopped a malaria epidemic by distributing medicine. The first baptism was preceded by a meeting of the village council where the three possibilities, Islam, Protestantism and Catholicism were discussed and the latter was chosen. This became a common pattern in the Kai islands, where conversions were collective rather than individual.

Notwithstanding the fact that Kai was part of a region with a strong Protestant tradition, the Resident of Ambon, D. Heyting (1883-1891) had sent a letter to all chiefs with the order that nobody should put obstacles in the way of the Catholic mission. The same is found in a later of recommendation of his successor as the Ambon Resident, G.W. van Hoëvell, who regretted that Christian mission did not start some years earlier. He estimated that of the 20,000 inhabitants of the Kai islands about one third had already embraced Islam "in its most fanatic form." ${ }^{29}$ During his first visit to Langgur this Resident even examined the schoolboys about their knowledge of the catechism and ordered them to sing the new Catholic hymns. In a conflict with the raja of Tual (when the new Catholics refused to pay taxes or forced contributions for the pilgrimage to Mecca of some elite of Tual) the Resident sided with the Catholics and made the village head of Langgur a chief in his own right with the same status as the Muslim chief (raja) of Tual. In 1902 there were already 1,170 baptised and 17 villages were declared 'Catholic' on the island of Kai Kecil.

\footnotetext{
${ }^{29}$ Steenbrink 2003-I:185.
} 
Elat, on neighbouring Kai Besar was in the first decade of the twentieth century the major centre for Protestantism, but about 1915 the native minister of the Protestant Mission moved to Tual, the centre of the government administration. In the mid-1920s the division of the religions in Kai with a population of 37,611 showed 13,360 Muslim (ca. 34\%), 10,749 Catholics (ca. 28\%) and 5,734 Protestants (ca. 18\%) and still 7,768 pagan. ${ }^{30}$ Since then the distribution of the three religions has not experienced drastic changes. As in the Central and Northern Moluccas, the adherents of the major religions opted for living in closed communities. In Kai and Tanimbar this process went together with the formation of larger settlements than the one or two family houses that until then had constituted the basic human settlement. All villages now have either a Muslim, Catholic or Protestant character, while in the major towns, like Tual, special quarters have their specific denominational character. ${ }^{31}$

Langgur became a central place for the Catholic mission. It was since 1902 the basis for the mission of the MSC (Sacred Heart Missionaries, Missionarii Sacri Cordis) and associated sisters who established large compounds with various schools. In 1940 there were 29 priests in the Moluccas, 25 brothers ( 4 of whom were native Indonesians) and 48 sisters, of whom 17 were native Indonesians. Of these 9 priests, 16 brothers and 23 sisters worked in the small town of Langgur in a great mission compound with a hospital, primary and secondary schools. The most important institution was the teachers training school that produced Catholic teachers not only for the Moluccas but also for Papua.

The Catholics still fostered the dream of a "return to the heritage of Saint Francis." In 1934 they celebrated with great pomp " 400 Years of Christianity in Indonesia," commemorating the Jesuit mission of the sixteenth century. However, in the island and town of Ambon itself they experienced great trouble in starting a Catholic parish. All native Christian Ambonese were now Protestants, while the small flock of Catholics in the capital of the residency consisted of some soldiers, government officials and Chinese traders who came from other regions. For this tiny community a parish was started in 1925, with only 352 faithful in 1938. Because of the dominant position of the town as capital of the regency 8 sisters had founded a Dutch language Catholic school in that town. In 1950 the town of Ambon became the centre of the Apostolic Vicariate and the seat of the bishop, who left Langgur because of the easier

\footnotetext{
${ }^{30}$ Mooij ed. 1925: 135; cf. Lasomer 1985:86. Since the 1920s there were no major changes in this division. In 1985 41\% were Muslim, 33\% Catholic and 25\% Protestant. Laksono 1996:156-176, esp. 158.

${ }^{31}$ For an anthropological account of this "rigid segregation between Catholic, Protestant and Muslim village" see Laksono 2002.
} 
communications in Ambon. This was notwithstanding the fact that until now very few native Ambonese have become Catholic and the majority of the faithful in the diocese of Ambon still are found in the Kai and Tanimbar islands. Of the total population of the Moluccas about 5\% is Catholic, and most live in the Southeastern islands.

For the South Moluccan mission the Japanese occupation was a very sad event, because of the cruelties of the Japanese navy which controlled the area. On 30 July 1942 Bishop Joseph Aerts together with 12 MSC priests and brothers were executed. As in many conflicts in this region also in Kai there was also some inter-religious rivalry involved. Mission sources blame an Arab from Tual as the main informant for the Japanese army and also a possible instigator for the cruel executions. Dutch colonial power certainly had given more facilities to Christian mission than to the spread of Islam. Therefore the close cooperation between the Muslim population and the Japanese can also be explained as a revenge for the neglect or even oppression of Islam in the colonial period. ${ }^{32}$

To fill the lowest level of colonial administration, the posthouder, usually better educated natives or Eurasians were employed and in this region of Indonesia they most often came from Ambon. Also for the administrative functions of police, and clerks in the office of the controleur, it was often Christian Ambonese who ware nominated to these positions. On the island of Tanimbar, where the Catholic mission had started about 1906, there were already some Ambonese Protestants active as teachers. They had already created a group of sympathisers for Protestantism, but were not allowed to administer baptism. About 1892 the Ambonese teacher Nicolaas Saliha from Ema came as the first Protestant teacher who settled on Tanimbar (Larat) and opened a school. He was followed in 1894 by Isaak Patty who worked on Selaru. The first teacher on Yamdena started in 1909 in Loro Ulung. ${ }^{33}$

For 1913 the statistics for all islands of the Tanimbar and Babar archipelago counted 5,530 Protestants in 31 congregations, with 14 native ministers, educated at the STOVIL in Ambon, 12 'catechists' or guru jemaat and five more evangelists, sent by the central office of the Indische Kerk in Ambon. Since the start of missionary work in this region, not anybody had been accepted as a full member of the Protestant Church, entitled to receive Holy Communion. These figures show both the missionary spirit of the lay members of the Ambonese branch of the Indische Kerk and its reservation about a hasty acceptance of members. The same can be said about the south-western islands of Wetar and Sermata. Mission work has started here already in the period 1820-1840

${ }^{32}$ Schreurs 1992:233-272.

${ }^{33}$ Steenbrink 2007:215. 
(among them Luycke and Bär) and had in 1897 already resulted in 9,342 baptised, of whom only 345 were allowed to receive Holy Communion. ${ }^{34}$

In the first decades of the twentieth century we see a whole range of conflicts between Catholics and Protestants on the Tanimbar Islands, where very few Muslims lived. Most of these conflicts were about the position of the teachers and often involved also the decision of villages or clans to opt for either Protestantism or Catholicism. The rivalry between the Catholic teachers from Kai (Langgur) and the Protestant teachers from Ambon resulted in one of the most debated Protestant baptising tours ever in this region. In 1918 Rev. G.C. van den Wijngaard, minister of the congregation of Banda, visited the southeastern islands and baptised on Tanimbar and some adjacent islands not less than 12,500 people. These people were prepared by Ambonese teachers in the region who had requested the coming of the Banda minister. His only demands were that people should ask for themselves for baptism and express their wish to become Christians; they should declare that they no longer put their confidence in the deities and spirits of their ancestors but in the one and only God who had created heaven and earth; they should solemnly promise to terminate all their pagan practices; they accepted the obligation to seek further Christian education as soon as possible in order to be admitted to the Holy Communion as well informed and pious Christians; they accepted the obligation to send their children to Protestant schools. ${ }^{35}$ In normal circumstances at least the recitation of Our Father, the Apostles Creed, and the Ten Commandments was requested, but in this case mass baptism was practised because of the rare travelling of a minister to the isolated islands and the danger of conversion to Catholicism. There are some more examples of this style of baptism, but never in such great number is in 1918 on Tanimbar. In these islands the number of Muslims remained very low, while the division between Protestants and Catholics showed a two-third majority of Protestants and a one-third portion for Catholics.

\section{8-2002 the Moluccan tragedy of inter-religious conflicts}

The first chapter of this book discussed the early race between Islam and Christianity, also related to East Indonesia. Whatever may have been its root cause, in the sixteenth and seventeenth century there were many conflicts between Christians and Muslims especially in the Moluccas as have been described in our first chapters. After the arrival of the Portuguese, the Muslims and Christians became divided in a mosaic of villages. There were and still are

\footnotetext{
34 Van den End 1989-II:64.

35 Enklaar 1947:71-75.
} 
more Muslim villages on the northern coasts of the islands, while Christians more often occupy the southern regions. But very often also there is a short distance between the two and not really a situation of larger Muslim regions clearly isolated from Christian regions. Notwithstanding the short distances between the two communities on many islands a practice of segregation had started. Christian and Muslim villages used to exist separated and in mutual exclusion. This continued in the Japanese period. The Muslim villages were closed off from direct colonial influence. There were many schools in the Christian villages. They had started as mostly religious schools, but were more oriented towards a mixed religious-profane curriculum since 1864 and were in the end fully integrated into the national school system, where the Moluccas were among the most progressive and modern regions. However, until 1942, the madrasah, the religious school of the Islamic villages, remained separated from this national educational system. Until the end of the Dutch colonial period there were very few elementary schools in Muslim villages.

During this period of isolation there were few conflicts between Christian and Muslim villages, at least not on a large scale. Both Muslim and Christian villages, especially in the Central Moluccas, felt perhaps that before all else they were united in the Agama Ambon. This was described by an anthropologist who did research in the late 1970s also as the "Nunusaku Religion" after the Banyan-mountain, from where all Ambonese originated according to their myth of origin. In this traditional religion also major elements of Islam and Christianity are incorporated, through an identification of this mountain with paradise, with Mount Ararat, where Noah's ark landed, and also with the place where the Last Judgement will occur.

The content, meaning, and ultimate end of Agama Nunusaku is Ambonese society itself. It deals with the peculiarities of Ambonese society, gives meaning to Ambonese identity, and is concerned with the perpetuation of Ambonese society and its continued well-being and the harmony between Christians and Moslems.... The Ambonese Christians see their own brand of Christianity as unique and specifically their own, to the point of exclusion of Chinese Christians from worship in Ambonese churches. Similarly, the Moslems exclude ethnically different groups from religious services in their mosques. Before World War II, they also chased out of the main mosque in Ambon city, those religious reformers from other parts of Indonesia who had come to preach the purification of Islam. Ambonese ethnic religion shows some parallels to what Bellah terms 'civil religion' in America. ${ }^{36}$

The unity of Muslims and Christians was further guaranteed and fostered by the pela-system of alliances between villages, often at great distances and of different religious affiliation. Although most alliances are between two

${ }^{36}$ Bartels 1977:319, referring to Bellah 1972:350-369. 
villages, there are also cases of three or more villages. Begun as an economic alliance, pela is also the cultic centre of Ambonese ethnic religion. ${ }^{37}$ It is not certain whether the pela-system originated before the colonial period (and thus even before the arrival of Islam and Christianity), or was constructed in the first half of the nineteenth century. It remained since the 'dim past' as the most important social bond which held society together. After the Indonesian independence (1945), the Ambonese Muslims, according to a very optimistic observer who did his fieldwork during the 1970s,

could have sought a strong identity primarily in Islam, distanced themselves from the stigmatised Christians and entered close ties with Islamic forces on a national level. But just as the Christians never severed their bonds with the Moslems when they themselves were swept to the top of the colonial hierarchy, the Moslems never cut their ties with the Christians when they found themselves in a superior position. The century-old links of pela were strong enough in both situations to prevent a break. Moslems and Christians have learned to trust and depend on each other and valued their proven relationship to such a high degree that they did not let other developments interfere with it.... Islam and Christianity are now subordinated to the goals of ethnic religion, but if the latter crumbles, the buffer between the two will be removed, leading to a direct confrontation, since these systems would move into the centre of beliefs in both groups. Ambonese Christians and Moslems would then deal with one another not primarily as Ambonese, but as Moslems and Christians first and Ambonese second. ${ }^{38}$

Through this pela-system, Muslims and Christians fostered the conviction that they were of the same origin, from the same Upu (ancestor). This can sometimes be seen in the names of villages like Siri-Sori Islam and Siri-Sori Kristen or in identical names for one clan that has Muslim and Christian members. The pela rituals and obligations were very successful in making the religious differences subordinate to the common genealogy. The few conflicts that arose during the last centuries most often were in quite remote areas, between Christians and Muslims as in the Kai or Sula archipelago, and they could be settled by local people themselves without interference by a regional or central government.

In the late 1960s, during the aftermath of the Soeharto-coup against the Communists, the issue of kristenisasi became prominent. This is the reproach by the Muslims of the Moluccas that the Christians tried to attain a majority in the Moluccas, or even to wipe out Islam through more intensive missionary campaigns. This was followed in the 1980s by the issue of 'proportionate personnel' at state institutions. As a prolongation of the colonial period when Christians rather than Muslims received Western education, jobs at government

37 Bartels 1977:320.

${ }^{38}$ Bartels 1977:324-325. 
offices and positions as teachers, from primary schools up to the Pattimura State University, were largely occupied by Christians. In the 1980s political correctness asked for the nomination of more and more Muslims to these traditional Christian bulwarks. Many government nominations were no longer based on quality and experience but on religious affiliation. From their side the Muslims felt that the Christians still held the highest positions and could not easily be removed at institutions like the Pattimura University.

On the local level this period from the 1960s to the 1990s saw many Muslim migrants from South and Central Sulawesi moving towards the Central Moluccas, especially to the town of Ambon. This caused a change in the already precarious religious balance of the region, where the Muslims had slightly outnumbered the Christians. The new migrants were looking for positions in the relatively prosperous economy of the Moluccas and threatened the job opportunities of local Muslims and Christians, both in the government and at private enterprises. The Christians felt hit twice, because local Muslims and newly arrived migrants were now taking 'their jobs.' This development threatened the earlier harmony between Muslims and Christians.

A further complicating factor in this process was the structure of the village administrations. During the 1960s the central government made new rulings for villages all over the country. In principle these regulations were modernising in a democratic spirit. Village heads should no longer be nominated along the feudal lines of ancestry, but should be elected by public vote after election campaigns by several candidates. The village also was to be called desa (different from the traditional name of negeri in the Moluccas) and the village head became kepala desa instead of the traditional title of raja. This new system eroded the traditional social structure with its respect for ancestors, and involved a number of conflicts and increased tensions related to elections. The traditional function of raja was only continued for rituals within the pela-system and some other customary ceremonies related to respect for the ancestors.

In this situation of growing tensions between the religious communities the issue of inter-religious dialogue became more and more important. It was a high priority in the policy of the central and provincial government whereby the central and provincial government (traditionally top-down) took many initiatives to improve relations between the religions. Not only churches and Muslim councils became active in encounters, the Protestant University of the Moluccas, UKIM, also became a member of the Research Institute for Inter-religious Relations (LPKUB, Lembaga Pengkajian Antar Umat Beragama). LPKUB was a joint enterprise of the Ministries of Religion and of Home Affairs, with a central office in Yogyakarta and branches in Medan and Ambon. The latter brought together lecturers of the Pattimura State University, the Protestant University of the Moluccas (UKIM), the Darussalam University (Muslim), the Trinitas Academy for Accountancy and Administration (Catholic) and the State 
Institute for Islamic Studies besides some representatives of the Buddhist and Hindu communities. Its objective was, "to collect the result of field research, as well as comprehensive ideas about various aspects of the inter-religious harmony in an effort to foster friendly, dynamic, creative and productive relations between the religions." ${ }^{39}$ In line with this initiative the theology of religions and the knowledge of other religions became an important topic at Christian and Islamic institutes.

Notwithstanding serious efforts to promote inter-religious harmony the growing atmosphere of tension exploded in a bloody series of clashes, attacks and counter-attacks in the period 1998-2002. One of the major reasons for this outburst may be sought in the uncertain state of the whole country of Indonesia after the fall of President Soeharto on 22 May 1998, after being in office for 32 years. He was succeeded by the former Vice President, Baharuddin Yusuf Habibie, who announced free elections for mid-1999.

From mid-November 1998 many pamphlets were spread in Ambon, containing mutual slander of Christianity and Islam by both parties with the threat that the time for a final battle and cleansing would come soon. On 14 November 1998 serious fights broke out between Christians of Hative Besar and their Muslim neighbours of Wailete, just across the town of Ambon along the bay, dividing the island of Ambon more or less into Christian Southern and Muslim Northern halves.

On 22 November 1998 a Jakarta based gang that controlled parking places, shops and also some gambling houses in Ketapang, North Jakarta, lead by the 'Christians' Milton Matuanakota and Ongky Pieters, lost a battle against a Muslim gang, from the Moluccan community in Jakarta, which was led by Ongen Sangaji: members of the Pemuda Pancasila, and of the Mahasiswa Muslim Maluku (Moluccan Muslim Students) who were hired by General Wiranto to fight anti-Habibie students in November 1998. Several hundred of the 'Christian group' returned to Ambon. Their opponents feared, that they would take revenge in the region (see also chapter six).

19 January 1999 was the start of the first period of cruel and bloody conflicts in Ambon. According to Muhammad Hussein ${ }^{40}$ it was " "an attack on Muslims, who were celebrating the end of Ramadan."' The riots started with a Christian ${ }^{41}$ preman or undisciplined youngster who did not pay a ticket for a car hired from a Muslim driver or owner (the Islamic version). Or was this just the story invented by Muslims who were already prepared to start the ethnic and religious cleansing

\footnotetext{
${ }^{39}$ Paragraph 4 of the Constitution of the LPKUB.

${ }^{40}$ Co-ordinator of the Forum Islam Maluku Bersatu Jabotabek, a Jakarta based organisation of Muslims, Republika, 11 Jan. 2000.

${ }^{41}$ Or a Muslim? There are various versions of this story as is the case with many details of the Moluccan tragedy. For several reports see Hartono 1999:55-56; Sinansari 1999:173-176.
} 
of Ambon (the Christian version)? Immediately after the fighting between these two persons some central districts of Ambon were full of rumours "that now the great war between Christians and Muslims had started." Shops were pillaged, houses burnt. From the very beginning Christian gangs used red headbands, and Muslims white ones. The death toll of the first day was reported as eleven. Within a few weeks the riots spread to all the villages in the island of Ambon and to the neighbouring islands, bringing the number of persons killed up to several hundred. The Al-Fatah mosque of Ambon became the central meeting point for Muslim activists and the Maranatha Church for the Christians. Christians were nicknamed 'Israel' or 'Obed' (after the name Robert for Christians), Muslims 'Palestinians' or 'Acang' (after the Muslim name Hasan). At the start of some fighting, girls or young women performed ritual dances (some of the women were among the victims of the fighting). The fighting became a civil war with fixed rituals and procedures. Quite often groups of youngsters deliberately walked towards the enemy, built simple blockades using cars and motorbikes, and started shooting from behind their positions.

From the beginning there were many rumours that the vehement fighting was incited by army generals who had lost their positions after the 1998 session of the National Congress, and who did not comply with the political reform, which would exclude them from the national politics and economy. They wanted to demonstrate that the new head of the army (Admiral Widodo, from the navy!) could not regulate even his own area, the Moluccan archipelago. It has been suggested that at all instances when retired General Wiranto was summoned to appear at the court for investigation, new riots in Ambon broke out. This theory states that elements from the army were the real power behind the violence and that the killings and destruction by the gangsters were only a smokescreen. ${ }^{42}$

The theory of outside, more specifically army involvement, can be corroborated by the rise of the violent group of Laskar Jihad. The group manifested itself for the first time during a prayer and information meeting, tablig akbar, held in the giant sports stadium of Senayan, Jakarta, on 6 April 2000. Some sources suggested retired General Prabowo, married to a daughter of ex-president Soeharto, as the man behind this group. Prabowo went to Jordan after the fall of Soeharto, because he was very close to the (then still) crown prince, Abdullah. Other reports suggest the name of the former Secretary General of the Tax Department, Fuad Bawazir, of Arab descent and with close connections in the Arab world, as the

42 "After initially using Ambonese gangsters as a smoke-screen, paramilitary forces close to Soeharto and troops loyal to Wiranto [dismissed as supreme commander of the army in early November 1999 and as Defence Minister on 15 February 2000] maintained the momentum of killings and destruction by continuously creating casualties on both sides that cried for revenge...," George Aditjondro, 'Playing Political Football with Moluccan Lives', an article that appeared at several places on the Internet. 
strong financial man behind the Laskar Jihad. Even the name of Bin Laden and the international terrorism of Afghanistan and Sudan have been mentioned in this matter. Laskar Jihad leader Jafar Umar Thalib was in the late 1980s for some time in Pakistan as a student and joined the Muslim forces in Afghanistan during this period. Needless to say, there is no firm proof of any major source of the financing required to mount the great undertakings of this militia. ${ }^{43}$

After the big demonstration in the Jakarta Senayan stadium on 6 April 2000, some 2000 Laskar Jihad members went into a training camp in Bogor, $80 \mathrm{~km}$. south of Jakarta. In Jakarta, Yogyakarta and Surabaya, along major streets shops offered the opportunity to sign contracts for joining the Laskar Jihad. 17 April the training camp moved to Kaliurang, a mountain resort north of Yogyakarta in Central Java. During the next two weeks several thousands Laskar Jihad members took boats for the Moluccas. ${ }^{44}$ The official position of the Laskar Jihad leaders was that their members went to "help Muslims in the islands with holy books, not swords and machetes." They were often supported by members of the regular army, while sections of the police force were reported to support the Christians. The local and rather small-scale fighting of the first tragic year, 1999, became in this way a continuing civil war with horrible consequences for the whole population who saw their houses, schools and shops destroyed and had themselves to escape to the less populated mountains in the island of Ambon, and to the surrounding islands. Many refugees had to go to regions like Minahasa or West Timor. Probably some 200,000 of the migrants of South Sulawesi and the island of Buton returned to their place of origin, or that of their parents, as this migration had already been under way for some 30 years. Only after the 12 October 2002 bombing in the tourist resort of Kuta, Bali, where nearly 200 foreign tourists were killed, was the Laskar Jihad disbanded, some gang leaders (including some military) called to court and the road to a more peaceful society opened.

It was not only Ambon that was the battlefield in this tragic conflict. In April 1999 most of the houses of the Christian population of the town of Banda, on the island known for its nutmeg, were burnt down. Many people were killed and others had to flee. Some Christians had to embrace Islam under threat of death and the men among them had to undergo circumcision on the spot. Even more forced conversions to Islam were reported from the Kesui islands (southeast of Seram).

${ }^{43}$ The Jakarta Post, 17 April 2000 quotes Laskar Jihad leader Jaffar Umar Thalib as saying that he had to fly to the Middle East to meet with his counterpart to talk about the planned deployment of volunteers in the Moluccas. He mentioned Saudi Arabia, Yemen and Jordan. See also Aditjondro 1999 and 2000.

${ }_{44}$ The Jakarta Post, 17 April 2000. In this case a different name for the same group, the Forum Ahlus Sunnah wal Jamaah was used. 
Many of the local conflicts had specific causes. On 31 March 1999 riots started in Tual (Kai Kecil). The long-standing quite peaceful relations between Muslims and Christians in these remote islands in the south-eastern region of the Moluccas changed drastically. It was the start of a long series of killings on the Kai islands, which caused half of the population of 100,000 to flee to safer places. Some suppose that there was a connection with the elections of June 1999, because of the close connections between religions and political parties. ${ }^{45}$ In Kai the riots remained restricted to conflicts in the first half of 1999 and soon afterwards reconciliation could begin.

The violence in North Halmahera became probably the worst in the whole region, for the period under discussion. Some claim at least 2500 dead between 18 August 1999 and the end of that year. The centre of riots and fighting was on the eastern coast of North Halmahera. The most serious conflicts in the (mostly Protestant) Kao-Tobelo-Galela region were related to migrations after several volcanic eruptions on the island of Makian (between Tidore and Bacan, off the West Coast of Halmahera) between 1975 and 1980. Some 17,000 (nearly all Muslim) inhabitants of Makian, many of them traders, were resettled amongst the small communities on the eastern coast of North Halmahera, mostly made up of Protestant farmers and fishers. In November 1999, after rumours that Makian Muslims had attacked a Kao village, the Christians started to set mosques on fire, whereupon many Makian settlers fled to the island of Ternate and killed a number of Christians in revenge. On 26 December massive killings in settlements of Makian Muslims started, which caused many reactions in other parts of Indonesia. The rise of Laskar Jihad, already discussed above, was often defended with reference to the Halmahera killings. A bloody and nearly complete civil war between Christian and Muslim parties started in Northern Halmahera with very little presence of the army until a period when people complained that this whole area was in total chaos and anarchy.

On 12 May 1999, in a period of relative rest, a large group of religious leaders, public figures and youth groups signed a peace pact at an open field in Ambon city. The Secretary General of the Synod of the greatest Protestant Church, Sammy Titaley, the Roman Catholic Assistant Bishop, Joseph Tethool, and R. Hasanusi, chairman of the Council of Muslim Scholars were present, besides the Governor, Muh. Saleh Latuconsina, and the national army commander Wiranto. ${ }^{46}$ This was only the first of a long series of efforts by religious leaders to calm the situation

${ }^{45}$ Apakabar, 4 April 1999. One of the few modern studies on Kai is by P.M. Laksono. He signals a religious division already since the 1930s when 61 villages were considered as Muslim, 45 Catholic and 41 Protestant. " The Dutch implemented a discriminatory policy against the Moslems. For example the Dutch ran only four public schools for all Islamic villages outside Tual, while subsidising seventeen Catholic and fourteen Protestant schools.”' (Laksono 1996:162).

${ }^{46}$ Kompas, 13 May 1999. 
and to call for peace and reconciliation. But as shown by the facts above, they had little influence on their communities where mostly male youngsters were responsible for the prolongation of the fighting.

During its 34th meeting the Synod of the GPM made an inventory of the losses between 19 January 1999 and February 2001. In six presbyteries (classes) the GPM could no longer execute its authority because the district offices were burnt down and the Christian population was chased away and stayed in refugee camps. The districts that were affected are: Banda islands, Taluti (Seram), Ternate, North Buru, Bacan, Obi (North Moluccas) and East Seram. 163 local congregations were in total or in majority expelled. As many as 15,612 families, totalling 82,906 members of this church, were among the refugees. 150 churches were burnt and 12,861 houses. ${ }^{47}$ On the Catholic side 66 churches were reported as burnt down, three were severely damaged. Also the place of pilgrimage of the Virgin Mary of Ahuru, Ambon, was totally destroyed. ${ }^{48}$ From the Protestant Church of Halmahera some 15,000 faithful were among the refugees who fled, most of them to the Minahasa. 7,000 houses and 120 churches were reported as totally destroyed. ${ }^{49}$ There are no detailed reports of the damage to mosques, Islamic schools and institutions, but on that side destruction was in comparable measure.

The civil war caused a drastic change in the service and pastoral care of the churches in this region. The traditional work was stopped when churches were destroyed and members had to flee. Besides care for the refugees, the first concern was the return of the citizens to their place of origin, because that was the place that was inhabited by their ancestors and the ownership of the ground was still guaranteed by public law. In the second half of 2002 the return could start in some regions: first of all to areas of Halmahera. It was common policy of the GPM that the refugees would not become members of the new local congregations but would remain within their former district, although they were now for some time far away from home.

Karel Steenbrink and Mesakh Tapilatu

\footnotetext{
${ }^{47}$ From the Report of the GPM Synod Himpunan Data Kerusuhan 19 Januari 1999 sampai dengan Pebruari 2001, Ambon, 2001.

${ }^{48}$ Information from the Diocese of Ambon, 2001.

${ }^{49}$ Interview with the head of the Synod of the Halmahera Protestant Church, Rev. Agustinus Ais, 1 November 2001.
} 


\section{Bibliography}

See the General Bibliography for Coolsma 1901, Enklaar 1947, Müller-Krüger 1966, Mooij 1927, Steenbrink 2003, Ukur \& Cooley 1979

Aditjondro, George

1999 "Guns, pamphlets and handy-talks: how the military exploited local ethno-religious tensions in Maluku to preserve their political and economic privileges." distributed through the internet, also in: Ingrid Wessel \& Georgia Wimhoefer (ed.), Violence in Indonesia. Hamburg: Abera, 2001.

1999-2000 "Playing Political Football with Moluccan Lives." An article that appeared at several places on the Internet.

Bartels, Dieter

1977-1981 "Guarding the Invisible Mountain: Inter-village Alliances, Religious Syncretism and Ethnic Identity among Ambonese Christians and Moslems in the Moluccas." [Ph.D. thesis, Cornell University] Ann Arbor, Michigan: University Microfilms International 1981.

Bellah, Robert N.

1972 "Civil Religion in America," in: Joseph Faulkner (ed.), Religious Influence in Contemporary Society. Columbus: Charles E. Merrill.

Enklaar, Ido Hendricus

1963 Joseph Kam, 'Apostel der Molukken'. 's-Gravenhage: Boekencentrum. [Bijdragen tot de zendingswetenschap; no. 4].

Fraassen, Chris F. van

1987 Ternate, de Molukken en de Indonesische Archipel: van soa-organisatie en vierdeling: een studie van traditionele samenleving en cultuur in Indonesië [Ph.D. Thesis Leiden]. S.n.

Fransz, A.L. (ed.)

1976 Benih yang Tumbuh IX: Suatu Survey mengenai Gereja Masehi Injili Halmahera. Jakarta: Lembaga Penelitian dan Studi Dewan Gereja-Gereja di Indonesia.

GPM Synod

2001 Himpunan Data Kerusuhan 19 Januari 1999 sampai dengan Pebruari 2001, Ambon.

Graaf, Hermanus J. de

1977 De geschiedenis van Ambon en de Zuid-Molukken. Franeker: Wever.

Haire, James

1981 The character and theological struggle of the church of Halmahera, Indonesia, 1941-1979. Frankfurt a.M. [etc.]: Peter Lang.

Hartono, Chris

1999 "The union of three Indonesian churches," Exchange 28-1:24-40.

Hoek, Antje van der

1994 Religie in ballingschap. Institutionalisering en leiderschap onder christelijke en islamitische Molukkers in Nederland. Amsterdam: VU uitgeverij.

Jong, Chris G.F. de

2002 "Uit de Dagboeken 3,4, en 5 van H.A.F. Wieënkotter, zendeling van het NZG op Ambon en Leti (een der Zuidwester-Eilanden), 1826-1828," Documentatieblad voor de Geschiedenis van de Nederlandse Zending en Overzeese kerken 9-1:50-81.

2006 De protestantse kerk in de Midden-Molukken 1803-1900. Een bronnenpublicatie. Leiden: KITLV, 2 vols.

Jong, Chris G.F. de \& Selm, M. van

1999 "Verslag van een reis naar de Zuidwester- en Zuidoostereilanden (Zuid-Molukken) door Joseph Kam (1825)", Documentatieblad voor de Geschiedenis van de Nederlandse Zending en Overzeese kerken 6-1:47-78.

Kroeskamp, Hendrik

1974 Early Schoolmasters in a Developing Country. A history of experiments in school education in 19th century Indonesia. Assen: Van Gorcum. 
Kromme, E.E.M.J.

1921 Beschrijving der Tanimbar en Babar-eilanden, ARA 2.10.36 KIT 1236.

Laksono, Paschalis Maria

1996 "Exchange and its Other. A Reflection on the Common Ground for the Kaiese," in: David Mearns \& Chris Healey (ed.), Remaking Maluku: social transformation in Eastern Indonesia, pp. 56-76. Darwin: Centre for Southeast Asian Studies, Northern Territory University.

2002 The Common Ground in the Kei Islands. Yogyakarta: Galang.

Lasomer, Xaf

1985 "Kei-eilanden: de uitbreiding van de Nederlandse invloed in de tijd van de Ethische politiek. Nijmegen" [Doctoraalscriptie Nijmegen: afdeling Economische en Sociale Geschiedenis Katholieke Universiteit].

Marantika, Simon

[1989] Bersama GPM melintasi masa pendudukan Jepang di Maluku, 1942-1945. Jakarta.

Protestantsche Kerk, De

1946 De Protestantsche Kerk in Indonesië tijdens bezetting en terreur. Batavia: N.V. Koninklijke Drukkerij de Unie.

Reenders, Homo

1991 Alternatieve Zending; Otto Gerhard Heldring (1804-1876) en de verbreiding van het Christendom in Nederlands-Indië. Kampen: Kok.

Schreurs, Peter G.H.

1992 Terug in het Erfgoed van Franciscus Xaverius: het herstel van de katholieke missie in Maluku, 1886-1960. Tilburg: Missiehuis MSC.

Sinansari Ecip, S.

1999 Menyulut Ambon. Kronologi Merambatnya berbagai kerusuhan lintas wilayah di Indonesia, Bandung: Mizan

Steenbrink, Karel A.

1974 "Pesantren, Madrasah, Sekolah; Recente ontwikkelingen in Indonesisch Islamonderricht." [Ph.D. Thesis, Catholic University of Nijmegen].

2001a 'Interpretations of Christian-Muslim Violence in the Moluccas', Studies in Interreligious Dialogue 11:64-91.

Wessel, Ingrid \& Georgia Wimhoefer (eds.)

2001 Violence in Indonesia. Hamburg: Abera. 